\title{
An Existential Ecofeminism and a Renewed Critical Theory of Nature: An Imagined Dialogue between Simone de Beauvoir and Jürgen Habermas ${ }^{1}$
}

\author{
Marcia Morgan
}

\begin{abstract}
Simone de Beauvoir has been commonly criticized for separating women from nature and attempting to make women "like men", as beings that dominate nature. I defend Beauvoir's existential concept of freedom as a non-sovereign relationship with nature. I then use the existential model constructed from my defense of Beauvoir as a framework with which to critique and engage Jürgen Habermas' 2001 intervention against liberal eugenics. My critique of Habermas is important because I would like to explore a renewed critical theory of nature from the perspective gained by an existential ecofeminism.
\end{abstract}

Key words: Ecofeminism; Critical theory of nature; J. Habermas; S. de Beauvoir; Liberal eugenics; Discourse ethics.

Um ecofeminismo existencial e uma renovada teoria crítica da natureza: um diálogo imaginado entre Simone de Beauvoir e Jürgen Habermas

Resumo: Simone de Beauvoir foi comumente criticada por separar as mulheres da natureza e tentar fazê-las ser "como os homens", como seres que dominam a natureza. Defendo o conceito existencial de liberdade de Beauvoir como uma relação não soberana com a natureza. Utilizo, então, o modelo existencial construído a partir de minha defesa de Beauvoir como um quadro com o qual se pode criticar e engajar a intervenção feita por Jürgen Habermas em 2001 contra a eugenia liberal. Esta crítica a Habermas é importante para minha intenção de explorar uma teoria crítica renovada da natureza a partir da perspectiva alcançada por um ecofeminismo existencial.

Palavras-chave: Ecofeminismo; Teoria crítica da natureza; J. Habermas; S. de Beauvoir. Eugenia liberal; Ética do discurso.

\footnotetext{
${ }^{1}$ Received on 15/08/2016 and accepted for publication on 14/12/2016.

${ }^{2}$ Associate Professor of Philosophy and Director of Women's and Gender Studies, Muhlenberg College (USA). E-mail: marciamorgan@muhlenberg.edu.
} 
$\mid 180$ |

An Existential Ecofeminism...

Ecofeminismo existencial y una teoría crítica renovada de la naturaleza: un diálogo imaginado entre Simone de Beauvoir y Jürgen Habermas

Resumen: Se ha criticado a Simone de Beauvoir por separar a las mujeres de la naturaleza y tratar de hacer que las mujeres sean "como los hombres", como seres que dominan la naturaleza. Defiendo el concepto existencial de libertad de Beauvoir como una relación no soberana con la naturaleza. A continuación, utilizo el modelo existencial construido a partir de mi defensa de Beauvoir como un marco con el que se puede criticar y enfrentar la intervención de Jürgen Habermas de 2001 en contra de la eugenesia liberal. Mi crítica de Habermas es importante porque me gustaría explorar una teoría crítica de la naturaleza renovada a partir de la perspectiva obtenida de un ecofeminismo existencial.

Palabras clave: Ecofeminismo; Teoría crítica de la naturaleza; J. Habermas; S. de Beauvoir; Eugenesia liberal; Ética del discurso.

\section{Introduction $^{3}$}

Simone de Beauvoir has been commonly criticized by first-generation ecofeminists for separating women from nature and attempting to make women like men, thus as beings that dominate nature. I will defend Beauvoir against this criticism by highlighting the existential constitution of her concept of freedom for women, which initially requires a separation from nature, but subsequently reintegrates women with nature as an emancipated social form. My analysis takes up Beauvoir's critique of freedom as sovereignty and connects it to man's desire for sovereignty in the face of nature. What is meant by "nature" in the present article is both human nature and the non-human natural environment. My

\footnotetext{
${ }^{3}$ I am thankful to the editors of this special issue, the editorial committee, and the anonymous external reviewers for their extremely helpful comments. I am also grateful for the comments and provocative questions from the scholars who participated in the Critical Theory Workshop at Yale University in October 2015 where I presented this paper, especially Seyla Benhabib, Nancy Fraser, Lenny Moss and Radu Neculau, and from the students and faculty colleagues who attended my presentation of this research as the keynote lecture at the University of Windsor graduate student conference in April 2016. I would also like to thank Mel Ferrara and Morgan P. Smith for their comments.
} 
argument thus elaborates Beauvoir's situational and existential concept of human freedom as a non- or anti-sovereign relationship with nature. I then use the existential model constructed from my defense of Beauvoir as a framework with which to engage and critique Jürgen Habermas' 2001 intervention against liberal eugenics. Although Habermas draws on an existential model of freedom - as a self-choosing of the limitations of one's own corporeal nature $[L e i b]$ - he nonetheless re-collapses the identity of the self with the body [Körper] and therefore backpedals against Beauvoir's feminist-existential advancements. In his stance against liberal eugenics Habermas emphasizes the ethical necessity of existential freedom as selbst-sein-können, or being able to be oneself, in the face of being-with-others, but inadvertently defers to a biologistic position as the foundation of his argument. My critique of Habermas is important not because it shows the inadequacy of the latter's argument against liberal eugenics or his feminist shortcomings, but rather because I would like to explore a renewed critical theory of nature from the perspective gained by an existential ecofeminism. This renewed capacity is elucidated through an imagined dialogue between Beauvoir and Habermas. This engagement could begin to offer a solution to critical theory's historical neglect of nature and move forward to a new critical theory of nature.

\section{Part I. Toward an existential ecofeminism: A defense of Beauvoir on freedom and nature}

"...if the body is not a thing, it is a situation..." Simone de Beauvoir, The Second Sex

In a chapter devoted to "Ecofeminism" in the comprehensive overview, Feminist Thought, Rosemarie Tong writes that "Beauvoir urged women to transcend their links to nature so as to overcome

\footnotetext{
${ }^{4}$ Beauvoir (2011), p. 46.
} 
$|182|$

An Existential Ecofeminism...

their status as the other, or second, sex. Beauvoir believed woman's identity as the other is derived partly from her biology - especially her reproductive capacity - and partly from her socially imposed child-rearing responsibilities" (TONG, 2014, p. 262)..$^{5}$ Tong asserts that Beauvoir "viewed woman's body as fundamentally alienating, as an energy drain leaving women too tired to participate in the kind of creative activity men enjoy" (ibid.), citing pages 19-27 of The Second Sex from the section titled "Destiny: The Data of Biology" - a title that Beauvoir means ambivalently and ironically. It is important to note that Tong is citing the first English translation of The Second Sex, which was completed in 1952 by a retired zoologist contracted to render this groundbreaking work accessible to an English audience by downplaying the existential composition of Beauvoir's argument, not fashionable and not easily marketable at the time. Indeed, as noted by the translators of the second English translation (published in 2011), what is missing from the first English translation is the philosopher herself, as well as the key existentialist terminology of her philosophical theory at the time. ${ }^{6}$ The pages cited by Tong provide detailed analysis of the differences between the sexes in several species, differences that problematize any essential difference between male and female across species, but nonetheless claim an unequal burden between male and female mammals in pubescent development, reproduction, and the body, with the weight of the burden falling on the female. The problem diagnosed by Beauvoir lies in the varying capacities of the genders to achieve autonomy vis-à-vis the body: one's own body, the body of the other (the child, the mating partner), and the nature of the species (BEAUVOIR, 1952).

Beyond the pages Tong references, but still within the same chapter, Beauvoir regards the bodily situation for women as a crisis:

\footnotetext{
${ }^{5}$ Tong is citing the older translation of The Second Sex (BEAUVOIR, 1952). For my analysis I have employed the newer translation by Borde and Malovany-Chevallier (BEAUVOIR, 2011).

${ }^{6}$ See the translators' “Introduction” and “Translators' Note” in Beauvoir (2011), p. ix-xxi.
} 
"here we find the most striking conclusion of the summary: namely, that woman is of all mammalian females at once the one who is most profoundly alienated (her individuality the prey of outside forces), and the one who most violently resists this alienation; in no other is enslavement of the organism to reproduction more imperious or more unwillingly accepted" (BEAUVOIR, 1952, p. 36). But this crisis - biologistically defined at this juncture in Beauvoir's investigation by taking the facts of biology inalterably as the given conception of the self - is overcome even within the same chapter, actually on the very same page. She writes:

\begin{abstract}
These biological considerations are extremely important. In the history of woman they play a part of the first rank and constitute an essential element in her situation... But I deny that they establish for her a fixed and inevitable destiny. They are insufficient for setting up a hierarchy of the sexes; they fail to explain why woman is the Other; they do not condemn her to remain in this subordinate role forever (ibid.).
\end{abstract}

And just a few pages later she is even more pointed: "Certainly these [biological] facts cannot be denied - but in themselves they have no significance. Once we adopt the human perspective, interpreting the body on a basis of existence, biology becomes an abstract science; whenever the physiological fact [...] takes on meaning, this meaning is at once seen as dependent on a whole context" (ibid., p. 38). And this context, according to Beauvoir, includes references to economic, social, moral and existential considerations (ibid., p. 39). Beauvoir underscores "possibilities" (ibid., p. 39-41), the capacities of individuals to be free - but always in broader social contexts and always in regard to a Mitsein, a "being-with" that entails oppositions. Beauvoir regards the male-female couple as an example of Mitsein, albeit a heteronormative case that will be complicated by later examples in her book. Crucial to Beauvoir's argument is the human perspective that reflects back on the biological facts of the self, not the biological facts themselves. Beauvoir is a dialectical thinker, and it is the 
|184 |

An Existential Ecofeminism...

deeply ironic nuances infused into her argument on individual freedom that have been overlooked and, frankly, overshadowed by the first English translation of her work, generating several hasty and overly generalized critiques.

For this reason I defend Beauvoir against the early ecofeminist critics because I take seriously the existential composition of her concept of freedom, which does not dominate nature but requires a distanciation from a purely corporeally defined selfhood for women, only to reintegrate women with nature and their own corporeality in the form of being-with-others as an emancipated social form. ${ }^{7}$ The initial distance allows for the recognition of one's autonomous capacity for self-authorship and self-narrativity in the face of being with others. Hence it is an autonomy defined by interdependence and intersubjectivity. We can understand Beauvoir's conception of freedom as interdependent, intersubjective and embedded within social relations, establishing an at times problematic social ontology - that is, questioning the ontological otherizing of women in their biologically given bodies - as a critique of freedom as sovereignty. Consider the philosophical implications of her metaphysical novel, She Came to Stay. As Debra Bergoffen (2014) has made clear, already in this earliest of entrances to her philosophic trajectory, Beauvoir is "examining the relationship and tensions between our singular existential status and the social conditions within which our singularity is lived". She Came to Stay vigorously questions Hegel's dictum that "Each conscience seeks the death of the other" (ibid.), certainly a masculinized motto for sovereign self-overcoming of alterity and what is most other to human consciousness and conscience: the nature of the biologically given, including the female body, all other bodies, and the naturally surrounding environment.

Beauvoir's understanding of freedom can thus be construed as anti-sovereign in that it avoids dominating any other, including the other within. As Bergoffen succinctly concludes: "Existential ambiguity trumps Hegelian clarity" (ibid.). Beauvoir makes clear

\footnotetext{
${ }^{7}$ In addition to Tong (2014), p. 255-92, see Diamond and Orenstein (1990).
} 
early on in The Second Sex that the biologically given nature of one's own sexed body is transcended by human relations and subsequently gains the possibility to be recast into a more positive connection through the social form of being-with-others (the Mitsein). The latter takes place through an understanding of laws and customs, and the enabling of conscious recognition of the self that can facilitate freedom in the face of these laws and customs (BEAUVOIR, 1952, p. 38-41). To demonstrate this, in concluding her chapter on "The Data of Biology," Beauvoir writes: "It is not merely as a body, but rather as a body subject to taboos, to laws, that the subject is conscious of himself and attains fulfillment - it is with reference to certain values that he evaluates himself. And, once again, it is not upon physiology that values can be based; rather the facts of biology take on the values that the existent bestows upon them" (ibid., p. 40-1). Mitsein is no guarantee of a positive connection to nature; but it is its only possibility, contingent upon economic, social, moral, and other factors. For this reason, Beauvoir argues for a greater collectivity of human existence in place of individual or solitary existence. I would emphasize here that Mitsein incorporates both a biologically given and an acculturated interpretation of nature that must work together positively and productively if the existent is to flourish and attain fulfillment. The being-with-others of Mitsein therefore implies the possibility of a positive connection to nature.

I disagree, therefore, with influential ecofeminist, Val Plumwood, who contends that when Beauvoir advocates for women to become fully human, the latter wants women to be "absorbed in a masculine sphere of freedom and transcendence conceptualized in human-chauvinist terms" (PLUMWOOD, 1986, p. 135 apud TONG, 2014, p. 263). Plumwood feared that Beauvoir was not granting women full personhood, but rather making them "men's full partners in the campaign to control or dominate nature". Plumwood continues, "The male-female dichotomy will not be bridged" (ibid.). ${ }^{8}$ Similar ecofeminist critics, such as

${ }^{8}$ See also Plumwood (1993).

Idéias, Campinas, SP, v.8, n.1, p. 179-202, jan/jun. 2017 
$|186|$

An Existential Ecofeminism...

Rosemary Radford Ruether, attributed to Beauvoir the principle of uncritical equality. However, Ruether succeeded rather in placing a static conception of women in the sphere of nature, sustaining a specious definition of the female that loses sight of Beauvoir's major advancements against essentializing femininity. In her attempt to overturn both models - the alleged uncritical equality of Beauvoir and the proposed uncritical reversal of Ruether -, Plumwood aims to collapse the double dichotomy of men/ women/culture/nature through a holistic oneness of men, women, and nature that eliminates all forms of domination. ${ }^{9}$ But unmediated and unreflective oneness reverts to an overly sentimentalized and dangerously romanticized "unity of life", as Plumwood herself recognizes in her later scholarship. ${ }^{10}$ We are reminded here of Herbert Marcuse's rejoinder that any celebration of the "unity of life" is premature; first we need to help those who are barely surviving (MARCUSE, 1941, p. 38-9). In this context Marcuse stands in solidarity with Beauvoir. We can take special note of his point that any "unity of life" is "the work of the subject's free comprehension and activity, and not of some blind natural force" (ibid.).

This is also Beauvoir's point, but from a different angle. She sees the subjugation of women in mid-twentieth century Europe rooted in the biologism of female nature, which serves as a false foundation and practically overpowering enabler of the culturally defined femininity at that time. From her construction of existential freedom, we inherit not another reinscription of the male-female

\footnotetext{
${ }^{9}$ See Plumwood (1993), especially Chapter 2 on “Dualism: The Logic of Colonisation”, p. 41-68.

${ }^{10}$ On this point see a helpful analysis by Colin Campbell (2011), p. 139-62. Although points in my analysis draw parallels to points made by Luc Ferry in Chapter 6 in critique of King and Ruether, for example, articulated in Ferry (1995), it should be clear that I do not agree with his conclusions. My divergence from Ferry is especially pointed through my agreement with Lee Quinby's claims and appropriation of Spivak on difference, captured, e.g., in Quinby (1990). For Plumwood's later distancing from the conception of unity, see Plumwood (2000) and (1998).
} 
binary with an accompanying alienation from nature (including human nature, non-human animals, and the natural environment), but a newly liberatory dichotomy of sex versus gender. And from the sex/gender binary we are the benefactors of a reading that does not appropriate the methodology of the male philosopher, but rather strives for a complete rehabilitation of philosophic methodology freed from a naturalistic imputation of biological difference to reason. This move in Beauvoir's work has been not only overlooked but in fact co-opted by her critics, and is further evidence in Beauvoir's favor of the ways in which the situations and contexts of women, including prominent female philosophers such as Beauvoir herself, are frequently read only in reference to the already male-defined species as given fact. In line with this, Susan Bordo (2015, p. 194) has pointed out that Beauvoir has been read by later feminists in a way that precisely corroborates Beauvoir's argument.

The ecofeminist literature cited above has appropriated Beauvoir's critique of the oppression of women's bodies and her construction of the sex-gender binary ${ }^{11}$, but simultaneously criticized her for upholding the immanent/transcendent dualism that ecofeminism aims to debunk. ${ }^{12}$ Again, this perspective does not adequately account for the irony in Beauvoir's factual accounts or the dialectical tensions she infuses into the descriptions. Nor does it address her explicit rebuttal of the activity/passivity dichotomy as having any appropriate application to sexual difference. But perhaps the most powerfully deconstructed binary in her analysis is that of strength and weakness in order to replace such a mythical foundation of permanent sexual difference with conceptions of the possibilities of transcendence in spheres such as ontology,

${ }^{11}$ One case of this comes from Ynestra King, e.g. in King (1981), although she then proceeds to define women as natural and embodying the reproductive/creative capacities of human making as Ruether has done as well.

${ }^{12}$ In addition to Tong, see Peter Hay (2002), p. 81-2. Chapter 3, on "Ecofeminism", is informative, although I disagree with Hay's critique of Beauvoir as eliminating ecological concerns from feminism. 
|188|

An Existential Ecofeminism...

psychology, economy, and "existence". For Beauvoir, strength is not sovereignty over the other, including one's self as a sexed body, but freedom with the other. Freedom comprises anti-sovereignty with others as a form of Mitsein in which one can be oneself to the fullest extent in a form of being-with-others, including with one's own body and with the naturally surrounding world. When the other is defined both as one's own given nature and the natural environment, we see Beauvoir's anti-sovereign model in full form.

Beauvoir did not seek power over the female body, other bodies or the natural environment, but understood any selfidentity as an intensive temporal implosion of selfhood in the context of any material situation. We can turn to Judith Butler's beautiful articulation of Beauvoir taking to task the Cartesian transcendent ego both in Sartrean existentialism and in all previous methodologies of the "Cartesian ghost", reversing the power of reason and the subordination of the female body and importantly differentiating between "the tension" of "being 'in' and 'beyond' the body" and "the move from the natural to the acculturated body" (BUTLER, 1987, p. 130-1). Butler adds: "...gender is not traceable to a definable origin because it itself is an originating activity incessantly taking place. No longer understood as a product of cultural and psychic relations long past, gender is a contemporary way of organizing past and future cultural norms, an active style of living one's body in the world" (ibid., p. 131). A developing autonomy of gender is itself a corporeal move not comprehensible within linear temporality. It is an implosion from within the moment of identity coherence that entails simultaneously past and future, enacting an incessant self-authorship and intermittent renarrativizing of the present. We see such a construction repeated throughout Beauvoir's entire oeuvre.

Susan Bordo has also compellingly backed up Beauvoir while simultaneously developing a corporeally-oriented feminism (BORDO, 1993). In her most recent scholarship on transnational feminism, Bordo includes Beauvoir as that seminal thinker who, according to Western philosophy's review of the book, gave philosophy a book "about women", but notes that it is frequently 
overlooked how much the book is also about other kinds of otherness, including Black identity (BORDO, 2015, p. 195). In her contributions to the discourse on otherness as multi-definitional, multi-faceted, multiply contextualized, and multiply contingent, Beauvoir opened up feminist theory for human nature, not just liberating women's bodies socially and culturally, but all bodies. Beauvoir's existential conception of freedom therefore provides an opening to an intersubjective, inter-contextualized as well as discursive-corporeal notion of emancipation via ecofeminism. In her 2005 text, Developing Ecofeminism, Erika Cudworth has attempted to build a discursively-oriented and renewed version of ecofeminism. ${ }^{13}$ She concludes her book by claiming that attempts to overcome the double logic of the domination of women and the domination of nature through discursive-corporeal frameworks have not found a way out of the matrix of domination, although she is sympathetic with this approach and has sought to achieve precisely an emancipatory solution through it. In the final sentences of her text she writes:

\begin{abstract}
Much as change may be a struggle, it is also so often embedded. We might not notice as our practices of daily life remake social structures through our sexual relations, kin relations, household formations, employment choice and practices, consumption patterns, use of "leisure" space and time. Incredible and dramatic change is much needed, is multifaceted, complex, complicated. It may all seem too much, too improbable and impossible. But potentialities for remaking our relations are embedded in the very detail of the matrix of domination (CUDWORTH, 2005, p. 178).
\end{abstract}

I would like to respond to Cudworth's conclusion by placing Beauvoir's achievements in conversation with

${ }^{13}$ See especially Chapter 7 on "Domination in a Lifeworld of Complexity", p. 156178. 
| 190 |

An Existential Ecofeminism...

ecofeminism and critiques of rationality from within discursive frameworks. We should feel compelled to embrace Beauvoir's existentialism as a robust dialogue partner with ecofeminist critiques of male sovereignty and overly rationalistic enterprises such as the "Cartesian ghost". I see this as an opening to further collaboration between existentialism, ecofeminism and recent critical theory in the form of discourse-corporeally based ethics. In what follows, I develop this further by engaging Beauvoir with Jürgen Habermas' recent intervention against liberal eugenics. As a preliminary conclusion, ending Part I, what I am calling an existential ecofeminism claims ecofeminism as an act of social and political resistance in defense of difference while retaining rational autonomy in a non-oppressive manner vis-à-vis the body and all "other nature". ${ }^{14}$

Part II: Habermas, existential freedom and the future of human nature

In her recent article on Simone de Beauvoir, Susan Bordo has reminded us of the former's depiction of women's lives as multiple, dispersed and contingent (BORDO, 2015, p. 196). Bordo also clarifies in reading Beauvoir both the material concreteness of these lives and the striving for an apt description of human nature (and not just female nature). To my judgment Beauvoir succeeded in confronting the possibility of any universal notion of human existence with the face of the socially and historically contingent and concrete. I would like to turn now to a contemporary intervention by Habermas, who has likewise managed the trapeze act between ethical universality and the contingency of historical materialism, as a means to develop the conversation into twenty-first century communicative ethics, ecocriticsm, and feminism, under the rubric of a renewed critical theory of nature.

\footnotetext{
${ }^{14}$ See Lee Quinby (1990).
} 
In "Remarks on Discourse Ethics", first published in 1991, Habermas incorporated a Gadamerian fusion of horizons into his discourse theory in which even conflicting standards of rationality are brought into a dialogue, dissolving the "us" against "them" bipolarity and removing the "false alternative between an assimilation 'to us' and a conversion 'to them"' (HABERMAS, 1993, p. 105). ${ }^{15}$ Relying further on Gadamerian hermeneutics, Habermas characterized the requirement of "a convergence between 'our' perspective and 'theirs' guided by learning processes, regardless of whether 'they' or 'we' or both sides must reform the practices of justification thus far accepted as valid" (ibid.). He aims to eliminate any possibility of fundamentalist perspectives by "anchor[ing] the same universalistic concepts of morality and justice in different, even competing, forms of life and show that they are compatible with different concepts of the good - on the assumption that the 'comprehensive doctrines' and 'strong traditions' enter into unrestricted dialogue with one another instead of persisting in their claims to exclusivity in a fundamentalistic manner" (ibid.).

To refute a possible objection that the idiosyncrasy and ontological singularity of any individual or group identity has been diminished in this account, he underscores the individuation process manifest in communicative socialization, indeed an individuation which "generates a deep-seated vulnerability, because the identity of socialized individuals develops only through integration into ever more extensive relations of social dependency" (ibid., p. 109). This dialectical structure enacts both individuality and collective identity through the mutually implicating nature of interpersonal relations. He clarifies as such: "The person develops an inner life and achieves a stable identity only to the extent that he also externalizes himself in communicatively generated interpersonal relations and implicates himself in an ever denser and more differentiated network of reciprocal vulnerabilities, thereby rendering himself in need

${ }^{15}$ Originally published as Erläuterung zur Diskursethik (HABERMAS, 1991). 
$|192|$

An Existential Ecofeminism...

of protection" (ibid.). In this way, singular individuality and ethical subjectivity arise out of and because of "a deep-seated vulnerability", which consequently creates the need for protection of the individual. Here exists the core of corporeal injurability. Habermas qualifies it with the statement that: "morality can be conceived as the protective institution that compensates for a constitutional precariousness implicit in the sociocultural form of life itself [...] Nobody can preserve his integrity by himself alone" (ibid.). Nonetheless, in this essay Habermas positions personal integrity above bodily integrity and grounds ethical subjectivity and the foundations of moral theory almost exclusively within the intersubjective horizon of social-communicative modes of interaction. This is clear when he differentiates between the human and the animal, the latter subsisting only in a bodily manner without personal integrity and thus receiving only a "quasi-moral" obligation from us, whereas the human "as persons can never leave the horizon" of intersubjective modes of interaction and therefore remain always in need of protection as moral agents to whom we are continuously obligated to ascribe personal integrity (see ibid., p. 109-10). This will change in his work in the twentyfirst century when he moves stridently in the other direction. In his most recent scholarship, the body [Leib] becomes almost the primary ground of personal identity and integrity, while his position still vibrantly retains the discourse-theoretical and communicative-ethical components from his earlier publications; this is evident in his most recent intervention on liberal eugenics.

If Habermas prioritized personal integrity over bodily integrity in his scholarship of the 1990s, he has certainly reconfigured this relationship in the 2000s. Let us recall a statement already cited from "Remarks on Discourse Ethics" (published in 1991): "The person develops an inner life and achieves a stable identity only to the extent that he also externalizes himself in communicatively generated interpersonal relations and implicates himself in an ever denser and more differentiated network of reciprocal vulnerabilities, thereby rendering himself in need 
of protection" (ibid., p. 109). With the publication of The Future of Human Nature in 2001, the personhood in "need of protection" in the discourse-theoretical context from the 1990s constituted by "communicatively generated interpersonal relations" now takes on such biological forms as a human embryo, a pregnant woman whose life is endangered, surrogate mothers, the terminally ill, those born with physically disabling conditions, and so on. This text represents Habermas' turn into a legal-political framework of the constitutional protection of human dignity. Here dignity is discussed and debated within the most bodily determined parameters. This is clear when he reintroduces a theme prominent from Helmut Plessner, namely, the distinction between having a body and being a body. ${ }^{16}$ This will relate to the ethical subjectivity at the heart of Habermas' intervention in the debate on liberal eugenics. He writes:

\begin{abstract}
A person "has" or "possesses" her body only through "being" this body in proceeding with her life. It is from this phenomenon of being a body and, at the same time, having a body [Leibsein und Körperhaben] that Helmut Plessner set out to describe and analyze the "excentric position" of man. Cognitive developmental psychology has shown that having a body is the result of the capacity of assuming an objectivating attitude toward the prior fact of being a body, a capacity we do not acquire until youth. The primary mode of experience, and also the one "by" which the subjectivity of the human person lives, is that of being a body [Leibsein] [my emphasis] (HABERMAS, 2003, p. 50).
\end{abstract}

${ }^{16}$ On the distinction between Leib and Körper, see Helmuth Plessner (1981), p. 296-303, 303-311, 367-382. The volume first appeared in 1928. The Suhrkamp Edition is from the second edition, which appeared 1966, expanded and edited. See also Plessner (1970), especially p. 23-47. 
| 194 |

An Existential Ecofeminism...

This is crucial for Habermas' differentiation between subjective and objective dimensions of personhood, what he calls "the grown" versus "the made" (ibid.), explicit in the example of the genetic manipulation of a human embryo (ibid.).

What is actively at play in Habermas' direct application of his own discourse-theoretical ethics and his more recently developed notion of existential freedom is the ability to choose oneself as one is (to become Leibsein or a lived body subjectively) out of the constraints of Körpersein or "having" a body objectively. This act of choosing is what manifests both ourselves and our ethicalcommunicative normative surroundings in and through which we enact our selfhood. In this initial move, Habermas' position is strikingly similar to Beauvoir's. Taking away the freedom to relate subjectively - the being that we are in our "inner" life or existential nature - to that which we are objectively - the body that we have through an "outer" nature - is the problem Habermas seeks to address in this debate (ibid.). However, Habermas' position falls behind Beauvoir's when he extends it to the human embryo. In his argument against liberal eugenics, he re-grounds existential freedom back into his discourse-theoretical position in the following way: the body that has been manipulated genetically has had no opportunity to respond. Habermas' main contention is that the body being imposed upon in the case of liberal eugenics has no framework to agree or disagree; in fact, the body cannot engage at all. This is what makes it unethical.

In contrast to Beauvoir's position, Habermas attributes meaning to the biological alone. Beauvoir emphasized that the biological in itself has no value; it only acquires values through the human perspective. Another problem arises in that the conception of existential freedom constructed by Habermas in this work is a reversal of the Kierkegaardian argument on which Habermas is relying. To clarify, let me go back to Habermas' appropriation of Kierkegaard's proto-existential notion of freedom in The Future of Human Nature:

[Kierkegaard] demands that I gather myself and detach myself from the dependencies of an overwhelming 


\begin{abstract}
environment, jolting myself to the awareness of my individuality and freedom. Once I am emancipated from a self-induced objectification, I also gain distance from myself as an individual [...] In the social dimension, such a person can assume responsibility for his or her own actions and can enter into binding commitments with others. In the temporal dimension, concern for oneself makes one conscious of the historicity of an existence that is realized in the simultaneously interpenetrating horizons of future and past (ibid., p. 6).
\end{abstract}

The freedom of the ethical subject in Kierkegaard is constituted contemporaneously with the act of recognizing one's freedom. Freedom only exists for Kierkegaard in the moment of the recognition of freedom, and recognition of freedom is only possible in the domain of human consciousness. In The Sickness Unto Death, freedom - and selfhood - can be grasped only as a verb, as a positionality in constant, active recognition of that which grounds it, which cannot be ascertained essentially. Freedom, for Kierkegaard, is the relation to the grounding force as an act of ungrounding. This positionality of constant, active recognition of that which grounds the self as an act of ungrounding facilitates a freedom from the anxiety of freedom that both Kierkegaard and Beauvoir diagnose.${ }^{17}$ While Kierkegaard and Beauvoir are certainly not offering the same model of existential freedom, the point of my critique of Habermas hinges on a common ground between Beauvoir and Kierkegaard, articulated in more detail immediately below.

The problem in Habermas' framework of existential freedom is that he imputes to the human embryo the possibility of the act of

\footnotetext{
${ }^{17}$ See Søren Kierkegaard (1983). For this reason, in Kierkegaard freedom is also only accomplished in the midst of a renunciation of an aestheticized distance from the self - a distance that lacks the irony of a second-order distinction of selfhood as active recognition in the face of the first-order distinction between the biologically-given and the rationally-comprehended and acted upon. See also Kierkegaard (1987).
} 
existential, active conscious recognition of the self, a possibility for authenticity. Moreover, Habermas claims that the nature I have been given biologically is that self from which I engage discursively, the self that ought to have the ability to respond. But the self from which I engage discursively, as Beauvoir pointed out, is the self of my Mitsein in being-with-others through my evaluation of the values I have been attributed societally. The Mitsein, in Beauvoir's notion of existential freedom, cannot exist prior to birth because it has no understanding of laws, customs, or social or economic considerations, among other factors. Therefore, there would never be any possibility of existential freedom for a human being prior to birth. Coming from a most religious perspective, Kierkegaard argues similarly that what matters for my positionality as an existing individual who embraces her own freedom in the form of active, conscious recognition is that I actively choose that over which I have had no control. I "choose" myself as I have been given prior to my existence as an ethical self. The paradox for Kierkegaard is that in the act of choosing myself I create my selfhood anew as my own existence. By definition, for Kierkegaard, the material ground of my existence is something that is always already decided for me. The ground of my choosing is always something over which I have no control, hence it is an ungrounding that refuses any essential definition of what I am as a self. For both Kierkegaard and Beauvoir, from rather different perspectives, this non-essentialism of the self is the source of freedom.

Habermas is thus redefining the "existence" in existential freedom, as formulated in Beauvoir and proto-existentially in Kierkegaard, by extending it in an a priori manner to the biology of the human embryo, that is, as an "existence" in an existential sense prior to birth. As stated in Part I of the present article, Mitsein for Beauvoir requires an interplay between the biologically given and the acculturated, social and existential self. For Beauvoir, the second-order self that has inherent within it the possibility for recognition of its own existential freedom is the self that Butler described as the incessant movement of corporeality and a 
qualitative transition in time that engages in discursive-corporeal significations with others.

In light of the above, Habermas is privileging the potential existential freedom of the not-yet-born over the current existential freedom of the existing parent. This raises implications and fruitful questions for both ecofeminism and a renewed critical theory of nature. My analysis means neither to diminish the need for intergenerational ethics which Habermas has so greatly advanced, on the one hand, or ecocritical theories of human nature, including arguments against liberal eugenics, on the other. I contend that Habermas provides us one of the most helpful and significant sketches of a future of human nature when we reintroduce Beauvoir's feminist achievements into the discussion. The argument against liberal eugenics requires a different logic than what Habermas has presented; it could draw from other dimensions of his intergenerational ethics in the form of intersubjective liability and corporeal injurability. ${ }^{18}$ Manipulation of human embryos ought to be limited, but for reasons other than those Habermas presents, yet reasons that are indeed generative of his own discursive-corporeal framework when thought together with Beauvoirean existential freedom. This juncture in my project is a point of new departure. I would like to conclude by turning to what has been gained from an engagement between Beauvoir and Habermas in the context of a renewed critical theory of nature.

\section{Conclusion: A renewed critical theory of nature}

Beauvoir's and Habermas' joint successes lie in the following areas: 1) their collective emphasis on the historical materialism of any individual human body in the face of ethical universality, 2) on an existential notion of autonomy as an incessant acting as a body, and 3) on an understanding of the body not as mere physical nature (Körper), but rather - or more importantly -

\footnotetext{
${ }^{18}$ See Morgan (2015).
} 
| 198 |

An Existential Ecofeminism...

as an existential relationship one bears toward one's physical body as a "thing" (Leibsein). How does this imagined dialogue between Beauvoir and Habermas furthermore speak to what I am calling a renewed critical theory of nature? Habermas has provided us with one of the most significant and productive constructions of a discursively-corporeal theory of human nature when we reintroduce Beauvoir's feminist-existential advancements. We eliminate the "us against them" bipolarism of previous theories, including those in the feminist criticisms and false appropriations cited in Part I of this article and in Habermas' staunch refusal of any fundamentalism in his discourse ethics, as articulated in Part II. Moreover, we can conceive of newly liberatory opening via discursive-existentially constructed notions of selfhood generated by a Beauvoirean critique of Habermas, as articulated in Part II.

What we have furthermore gained from an imagined dialogue between Beauvoir and Habermas is a renewed understanding of a needed critical theory of nature that does not take us back to sentimentalized hopes for the possibility of an untouched nature in any speciously essentialized manner, including a problematic idea of a "pure" human nature unmediated by society, or a nature experimentally posited as an ideal toward which we could work and through which we could become emancipated from society's false ideologies and destructive constraints. Quite the contrary, I would like to conclude in solidarity with recent scholarship that works against the reification of nature in the tradition of critical theory. For example, Andrew Biro has underscored the antinomy embedded within our contemporary predicament as we seek to avoid essentializing nature, on the one hand, and yet aim to limit domination over nature, on the other. ${ }^{19} \mathrm{I}^{\prime} \mathrm{m}$ thinking here mainly of two significant books: Steven Vogel's 2015 publication, Thinking Like a Mall: Environmental Philosophy After the End of Nature, and Biro's 2005 monograph on Denaturalizing Ecological Politics: Alienation from Nature from Rousseau to the Frankfurt School and Beyond. These

\footnotetext{
${ }^{19}$ See, e.g., Andrew Biro (2003). See also Biro (2005).
} 
two examples of contemporary environmental ethics from the standpoint of contemporary critical theory add an explicit ecocritical dimension to my framework. In his early work, in a book titled Against Nature, Vogel made clear that we have been well instructed by the early critical theorists (including Georg Lukács and the first and second generation Frankfurt School thinkers) that there is no given "nature" (VOGEL, 1996). ${ }^{20}$ Vogel concludes his monograph by turning to Habermas and discourse ethics, entering what we could now call a theory of communicative authenticity in our engagement against any domination over human nature or the natural environment. I believe that the imagined dialogue between Beauvoir and Habermas could lead into additional, productive directions for a reconsideration of nature from within an existential understanding of freedom. We reach an asymptotic limit when we attempt to impute this understanding of freedom onto that which precedes the Mitsein of social, legal, moral, economic and other customs and existential contexts or situations. A renewed critical theory of nature reminds us of our own limitations in the sphere of human nature, and urges us to think more critically about our own human constructions, instead of dominating all "other" "nature". This point could serve as a rejoinder to advocates of liberal eugenics, but with a logic different from the one Habermas has employed and yet in the spirit of Habermas' tremendous achievements for critical theory.

${ }^{20}$ See also his most recent work, Vogel (2015). 
| 200 |

An Existential Ecofeminism...

\section{References}

BEAUVOIR, Simone de. The Second Sex. Trans. H. M. Parshley. New York: Vintage Books, 1952.

The Second Sex. Trans. Constance Borde and Sheila MalovanyChevallier. New York: Vintage Books, 2011.

BERGOFFEN, Debra. Simone de Beauvoir. In: Stanford Encyclopedia of Philosophy. 2014. Available at: <https://plato.stanford.edu/entries/ beauvoir/>. Accessed: 15 Jan. 2016.

BIRO, Andrew. Towards a Denaturalized Ecological Politics. Polity, v. 35, n. 2, p. 195-212, 2003.

Nature or "Nature"? Ecological Politics and the Postmodern

Condition. In: Denaturalizing Ecological Politics: Alienation from Nature from Rousseau to the Frankfurt School and Beyond. Toronto: University of Toronto Press, 2005, p. 3-11.

BORDO, Susan. Unbearable Weight: Feminism, Western Culture, and the Body. Berkeley: University of California Press, 1993.

Simone de Beauvoir: The Feminist Philosopher as Other. In: BORDO, Susan; ALCALDE, M. Cristina; ROSENMAN, Ellen (eds.). Provocations: A Transnational Reader in the History of Feminist Thought. Oakland: University of California Press, 2015, p. 193-99.

BUTLER, Judith. Variations on Sex and Gender. In: BENHABIB, S.; CORNELL, D. (eds.). Feminism as Critique. Minneapolis: University of Minnesota, 1987, p. 128-142.

CAMPBELL, Colin. From "Unity of Life" to the Critique of Domination: Jonas, Freud, and Marcuse. In: BIRO, Andrew (ed.). Critical Ecologies: The Frankfurt School and Contemporary Environmental Crises. Toronto: University of Toronto Press, 2011, p. 139-62.

CUDWORTH, Erika. Developing Ecofeminist Theory: The Complexity of Difference. New York: Palgrave Macmillan, 2005. 
DIAMOND, Irene; ORENSTEIN, Gloria Feman (eds.). Reweaving the World: The Emergence of Ecofeminism. San Francisco: Sierra Club Books, 1990.

FERRY, Luc. In Praise of Difference, or the Incarnations of Leftism: The Case of Ecofeminism. In: The New Ecological Order. Chicago: University of Chicago Press, 1995, p. 108-26.

HABERMAS, Jürgen. Erläuterung zur Diskursethik. Frankfurt am Main: Suhrkamp, 1991.

Remarks on Discourse Ethics. In: Justification and Application. Trans. Ciaran Cronin. Cambridge, MA and London: MIT Press, 1993, p. 19-111.

The Future of Human Nature. Trans. William Rehg, Max Pensky and Hella Beister. Cambridge: Polity Press, 2003.

HAY, Peter. Main Currents in Western Environmental Thought. Bloomington and Indianapolis: Indiana University Press, 2002.

KIERKEGAARD, Søren. The Sickness Unto Death. Trans. Hong and Hong. Princeton: Princeton University Press, 1983.

Either/Or, vol. I and vol. II. Trans. Hong and Hong. Princeton: Princeton University Press, 1987.

KING, Ynestra. Feminism and the Revolt of Nature. Heresies, n. 13: Earthkeeping/Earthshaking: Feminism \& Ecology, p. 12-16, 1981.

MARCUSE, Herbert. Reason and Revolution. London: Routledge and Kegan Paul, 1941.

MORGAN, Marcia. Heller and Habermas in Dialogue: Intersubjective Liability and Corporeal Injurability as Foundations of Ethical Subjectivity. Revue Internationale de Philosophie, v. 3, Brussels, p. 303-320, 2015.

PLESSNER, Helmuth. Laughing and Crying: A Study of the Limits of Human Behavior. Trans. J. S. Churchill and M. Greene. Evanston, IL: Northwestern University Press, 1970. 
Die Stufen des Organischen und der Mensch. Einleitung in die philosophische Anthropologie. In: Gesammelte Schriften, vol. 4. Frankfurt am Main: Suhrkamp, 1981.

PLUMWOOD, Val. Ecofeminism: An Overview and Discussion of Positions and Arguments. Australian Journal of Philosophy, v. 64, supplement, p. 120-138, 1986.

Feminism and the Mastery of Nature. London and New York: Routledge, 1993.

Nature, Self, and Gender: Feminism, Environmental Philosophy, and the Critique of Rationalism. In: ZIMMERMAN, M. et al. (eds.). Environmental Philosophy. Upper Saddle River, NJ: Prentice Hall, 1998, p. 291-314.

Deep Ecology, Deep Pockets, and Deep Problems: A Feminist Ecosocialist Analysis. In: KATZ, A; LIGHT, E. and ROTHEMBERG, D. (eds.). Beneath the Surface: Critical Essays in the Philosophy of Deep Ecology. Cambridge, MA and London: MIT Press, 2000, p. 59-84.

QUINBY, Lee. Ecofeminism and the Politics of Resistance. In: DIAMOND, Irene; ORENSTEIN, Gloria Feman (eds.). Reweaving the World: The Emergence of Ecofeminism. San Francisco: Sierra Club Books, 1990, p. 122-7.

TONG, Rosemarie. Feminist Thought. Boulder, CO: Westview Press, 2014.

VOGEL, Steven. Against Nature: The Concept of Nature in Critical Theory. Albany: State University of New York, 1996.

Thinking Like a Mall: Environmental Philosophy After the End of Nature. Cambridge, MA: MIT Press, 2015. 